\title{
ANALISIS DIMENSI KUALITAS PELAYANAN Dan EFEKTIVITAS STRATEGI OPERASIONAL Pada FIRMA HUKUM MAP
}

\author{
Aisyah Pia Asrunputri \\ Alumni Magister Manajemen Universitas Gadjah Mada \\ Email: aisyahpia@yahoo.com
}

\begin{abstract}
This study focuses on how firma hukum MAP fulfils its clients' expectations of its service from the perspective of SERVQUAL dimensions. This study also examines the effectiveness of the operational strategy, which is employed by firma hukum MAP in executing its day-to-day operation. The author uses focus group discussion and in-depth interview to collect data for this study. According to the findings, the service quality of firma hukum MAP has already fulfilled its clients' expectations also is valued to be satisfactory, so does the operational strategy of firma hukum MAP. Firma hukum MAP has been successfully implementing its operational strategy, which is waste elimination to help firma hukum MAP to smooth out their daily business process. However, there are some improvements needs to be made. Some of them are by continuously improving its performance throughout the time, by implementing CRM and by benchmarking against the best practice law firm in the industry.
\end{abstract}

Key words: SERVQUAL, Waste Elimination, CRM.

\begin{abstract}
ABSTRAK
Penelitian ini berfokus pada bagaimana firma hukum MAP memenuhi ekspektasi kliennya mengenai pelayanan berdasarkan dimensi SERVQUAL. Penelitian ini juga mengevaluasi efektivitas dari strategi operasional firma hukum MAP. Peneliti menggunakan focus group discussions dan in-depth interview untuk memperoleh data penelitian ini. Berdasarkan penemuan dari penelitian ini firma hukum MAP telah memenuhi ekspektasi klien serta pelayanan hukum yang telah diberikan oleh firma hukum MAP juga sudah memuaskan. Firma hukum MAP dinilai telah sukses mengimplementasikan strategi operasional yakni dengan menggunakan strategi waste elimination yang mana membantu firma hukum MAP untuk menghadapi tantangan bisnis dalam sehari-harinya. Namun terdapat beberapa perbaikan yang perlu dibuat yakni dengan meningkatkan performa pelayanan dengan mengimplementasikan CRM dan juga dengan melakukan benchmarking.
\end{abstract}

Kata Kunci: SERVQUAL, Waste Elimination, CRM. 


\section{A. PENDAHULUAN}

Alasan penulis memilih topik yang berjudul "Analisis Dimensi Kualitas Pelayanan dan Efektivitas Strategi Operasional Pada Firma Hukum MAP” yang pertama adalah untuk mengukur seberapa besar Kantor Advokat MAP memenuhi harapan konsumen dalam menjalani usahanya dari perspektif servqual (service quality) yang bertumpu pada focus group discussion. Sementara yang kedua adalah dengan melihat dari perspektif strategi operasional yang terfokus pada waste elimination menggunakan metode pengumpulan data primer yakni in-depth interview. Tujuannya adalah untuk menjelaskan mengenai implementasi strategi operasionalnya pada Firma Hukum MAP yang berfokus pada bagaimana Firma Hukum MAP memiliki strategi untuk memberikan pelayanan konsultasi hukum sampai dengan prosedur berita acaranya di pengadilan.

Topik ini menitikberatkan pada kualitas servis dari Firma Hukum MAP dan implementasi strategi operasionalnya. Kualitas sendiri bermakna kondisi dinamis yang berpengaruh terhadap produk atau jasa. Apabila sebuah perusahaan memenuhi harapan dari konsumen maka produk atau jasa yang diciptakan akan diterima dengan baik oleh konsumen. Kualitas tersebut dapat diukur dengan menggunakan perspektif konsumen yang telah memiliki pengalaman dalam menggunakan barang atau memiliki pengalaman menggunakan jasa perusahaan tersebut. Pada penelitian ini, penulis akan menggunakan servqual untuk mengukur kualitas jasa dari perspektif konsumen. Servqual memiliki 5 dimensi yakni tangibles, reliability, responsiveness, assurance, dan empathy. Sedangkan dari perspektif strategi operasionalnya akan menjelaskan mengenai tingkat efisiensi dan efektivitas dari Firma Hukum MAP dalam menjalani usahanya dengan cara mengeliminasi waste atau pemborosan yang tidak menambah nilai pada produk atau jasa dari firma hukum tersebut. Thomson Reuters (2014) membagi waste tersebut menjadi beberapa kategori yakni: defects, over production, non-utilized talent, transportation, dan extra processing.

Firma hukum MAP didirikan oleh Dr. Andi Muhammad, S.H., M.H pada tahun 2006 yang melibatkan beberapa advokat dan konsultan hukum dalam kegiatan jasa hukumnya. Dr. Andi Muhammad, S.H., M.H selaku pendiri lahir di Makassar pada tanggal 19 November 1959 dan lulus dari Fakultas Hukum Universitas Indonesia dan mendapatkan gelar doktornya pada tahun 2003. Dr. Andi adalah dosen senior dari Fakultas Hukum Universitas Pakuan Bogor juga pernah menjadi pemimpin sebuah LSM yang bernama Judicial Watch Indonesia dan merupakan anggota dari Coalition of International Criminal Court di New York.

Melalui pengalaman luas dan keahlian dari managing partner beserta para advokat dan konsultan hukum MAP lainnya, MAP memiliki pengalaman yang luas dalam mewakili klien baik dalam perkara Litigasi maupun Non-Litigasi. Sebagai kantor hukum, MAP memberikan pelayanan maksimal kepada para kliennya dan memastikan bahwa para advokat dan konsultan hukumnya dapat memberikan solusi yang terbaik yang disesuaikan dengan kebutuhan para klien terkait dengan penanganan perkara.

MAP memberikan jasa hukum dengan kekuatan khususnya dalam persidangan di Mahkamah Konstitusi dan Peradilan Umum guna mendukung dan 
memenuhi kebutuhan hukum klien dalam berbagai aktivitas. Ruang lingkup tersebut meliputi jasa hukum secara Litigasi dan Non Litigasi. Untuk jasa litigasi di Mahkamah Konstitusi, MAP memiliki kekuatan dalam melakukan penanganan secara litigasi dalam bentuk persidangan di Mahkamah Konstitusi, baik untuk sengketa Pemilu, Pilkada maupun Permohonan Uji Materil Undang-Undang terhadap Undang-Undang Dasar 1945.

Sedangkan jasa Non Litigasi, MAP banyak berperan sebagai konsultan tetap, baik perorangan, badan hukum swasta, milik daerah, serta lembaga pemerintahan dalam rentang waktu tertentu, minimal satu tahun. Dalam rentang waktu tersebut, klien mendapat berbagai layanan konsultasi secara berkala atau dalam kondisi tertentu sesuai dengan tingkat kebutuhan. Konsultasi yang diberikan sesuai permintaan dan menyangkut praktek hukum yang berlaku di Indonesia, termasuk menjadi konsultan para calon peserta pemilihan kepala daerah serta memberikan legal due diligence (LDD) dan review peraturan perusahaan dan atau peraturan daerah atau lembaga.

Selain itu, MAP juga memberikan layanan penanganan litigasi pada persidangan peradilan umum di bidang berikut: Hukum Konstitusi, Hukum Tata Negara, Hukum Pemerintahan Daerah, Hukum Keperdataan, Hukum Pertanahan dan Properti, Hukum Tata Usaha Negara, Hukum Pidana, Hukum Ketenagakerjaan atau Perselisihan Hubungan Industrial. Tujuan dari penelitian adalah Menganalisis dimensi kualitas pelayanan dan mengevaluasi kemungkinan adanya service quality gap pada firma hukum MAP dan Menganalisis efektivitas strategi operasional pada firma hukum MAP.

Lingkup Penelitian Penelitian ini bersifat eksplanatif yang mana didesain untuk mengukur kualitas pelayanan dari firma hukum MAP berdasarkan dimensi SERVQUAL serta untuk mengukur efektivitas strategi operasional dari firma hukum MAP dengan memfokuskan pada waste elimination strategy.

\section{B. TINJAUAN PUSTAKA}

\section{Manajemen Kualitas}

\section{Konsep Kualitas}

Kualitas bermakna suatu strategi dasar bisnis yang menghasilkan barang dan jasa yang memenuhi kebutuhan dan kepuasan konsumen internal dan eksternal. Suatu produk atau jasa yang berkualitas memiliki ciri-ciri: 1) bila produk atau jasa tersebut memenuhi atau melampaui harapan konsumen bukan satu kali saja tetapi berulang kembali 2) bila produk atau jasa tersebut memberikan kepuasan kepada konsumen. Kualitas telah menjamin isu kritis dalam persaingan dewasa ini dan hal itu telah menjadi tantangan bagi para pelaku usaha. Dalam tataran abstrak kualitas telah didefinisikan oleh seorang pakar penting dibidang kualitas yakni Joseph Juran dan Deming. Mereka berhasil menjadikan kualitas sebagai sesuatu yang terus berkembang dalam kajuan manajemen khususnya manajemen kualitas (Juran dan Deming; Mulia, 2011).

Berdasarkan penelitian oleh Juran (1998) dalam (Mulia, 2011), kualitas adalah kesesuaian untuk penggunaan (fitness for use) yang berarti produk atau 
jasa harus sesuai dengan yang diperlukan atau diharapkan oleh pengguna. Untuk lebih jauh, Juran mengemukakan lima dimensi kualitas yakni:

1. Rancangan (design) sebagai spesifikasi produk atau jasa

2. Kesesuaian (conformance) yang bermakna kesesuaian antara maksud desain dengan penyampaian produk atau jasa aktual

3. Ketersediaan (availability) yang mencakup aspek kedapatdipercayaan serta ketahanan dan kesediaan produk atau jasa bagi konsumen untuk digunakan

4. Keamanan (safety) yang bermakna aman dan tidak membahayakan konsumen

5. Guna praktis (field use) kegunaan praktis yang dapat dimanfaatkan pada penggunaan oleh konsumen

\section{SERVQUAL (Kualitas Servis)}

Konsep SERVQUAL

Konstruksi kualitas sebagaimana dikonsepkan dalam literatur servis dan diukur menggunakan SERVQUAL yang mana skala tersebut menggunakan persepsi kualitas dari konsumen. Persepsi kualitas dari konsumen tersebut adalah penilaian mengenai kehebatan atau superioritas dari servis tersebut. Persepsi tersebut adalah bentuk dari perilaku konsumen tetapi tidak langsung berkaitan dengan kepuasan melainkan dari perbedaan ekspektasi dari konsumen mengenai performa servis (PARASURAMAN, 1988).

Penilaian konsumen terhadap kualitas sangat penting bagi perusahaan karena ekspektasi konsumen tersebut berfungsi sebagai fondasi dalam mengevaluasi kualitas servis karena ketika kualitas jasa itu tinggi ketika ekspektasi itu terwujud dan kualitas jasa itu rendah apabila performa dari servis itu tersebut tidak memenuhi ekspektasi konsumen. Oleh karena itu, perusahaan yang bergerak dibidang jasa harus dapat memahami perilaku konsumen lebih baik untuk dapat melayani konsumen dengan baik sehingga dapat memenuhi ekspektasi konsumen mengenai jasa yang ditawarkan.

\section{Dimensi SERVQUAL}

Berdasarkan Iwaarden et al (2003) dalam (Shahin, 2010). Terdapat 5 dimensi generik atau faktor-faktor yang terdapat dalam dimensi SERVQUAL yakni:

1) Tangibility, yaitu fasilitas fisik, peralatan dan penampilan dari pelayanan suatu perusahaan.

2) Reliability, yaitu kemampuan untuk berperforma servis yang dijanjikan secara akurat.

3) Responsiveness yaitu kesediaan pegawai membantu konsumen dan menyediakan servis tepat waktu.

4) Assurance yaitu termasuk kompetensi, kesopanan, kredibilitas dan keamanan.

5) Emphaty yaitu akses, komunikasi dan memahami konsumen serta peduli dan perhatian terhadap konsumen oleh perusahaan. 


\section{Waste Elimination}

Untuk mencapai keefektivitasan dan efisiensi dalam menghasilkan servis dan operasional yang berkualitas sehingga dapat meningkatkan kepuasan konsumen, firma hukum harus dapat menciptakan suatu solusi melalui strategi operasional. Salah satu strategi operasional adalah strategi pengeliminasian pemborosan (waste elimination). (Lisa Glanakos, 2014) mengelompokkan waste dalam firma hukum itu sendiri dalam beberapa kategori yakni defects, over production, non-utilized talent, transportation, dan extra processing.

Tabel 1.

Tipe Pemborosan Dan Contoh

\begin{tabular}{|c|c|}
\hline $\begin{array}{c}\text { TIPE } \\
\text { PEMBOROSAN } \\
\end{array}$ & CONTOH LEGAL \\
\hline Defects & $\begin{array}{l}\text { Kesalahan, sebagai contoh, sedikitnya riset yang dilakukan } \\
\text { menghasilkan pelayanan konsultasi hukum yang buruk. Legal } \\
\text { error juga dapat terjadi karena adanya poor proofreading. }\end{array}$ \\
\hline Over Production & $\begin{array}{l}\text { Penulisan dokumen yang mana, terlalu banyak ronde dari } \\
\text { peninjauan sehingga menghasilkan dokumentasi yang mahal. }\end{array}$ \\
\hline Non-Utilized Talent & $\begin{array}{l}\text { Advokat tidak membuat quota dikarenakan kurangnya rencana } \\
\text { penggunaan sumber daya atau kelebihan estimasi mengenai } \\
\text { jumlah pekerjaan yang akan diberikan kepada karyawan. }\end{array}$ \\
\hline Transportation & $\begin{array}{l}\text { Pemindahan informasi dalam bentuk fisik ketika internet } \\
\text { sebenarnya dapat mengurangi biaya transportasi untuk } \\
\text { pemindahan informasi tersebut. }\end{array}$ \\
\hline Extra Processing & $\begin{array}{l}\text { Terlalu banyak langkah dalam workflow yang sebenarnya tidak } \\
\text { dibutuhkan dan tidak menambah nilai seperti chain of command } \\
\text { yang terlalu panjang. }\end{array}$ \\
\hline
\end{tabular}

Sumber: Thomson Reuters (2014).

\section{METODOLOGI PENELITIAN}

Penelitian empiris ini menggunakan data sekunder dari beberapa jurnal ilmiah terkait manajemen dan hukum. Data primer yang digunakan oleh peneliti sendiri bersumber dari focus group discussion dan in-depth interview di firma hukum MAP.

\section{PEMBAHASAN}

\section{Focus Group Discussion}

Penulis telah melakukan focus group discussion dengan beberapa klien yang telah menikmati pelayanan dari firma hukum MAP. Keempat klien tersebut telah menikmati pelayanan hukum dari MAP yang terfokus pada perkara hukum tata negara. Hukum tata negara yang mayoritas kasus yang ditangani adalah mengenai uji perundang-undangan baik dari segi tergugat maupun yang menggugat. 
Pertanyaan focus group discussion ini sendiri terbagi atas 9 bagian dan dilakukan secara anonim berdasarkan keinginan klien dari firma hukum MAP itu sendiri. 9 bagian itu meliputi: 1) pengetahuan mengenai firma hukum MAP, 2) tipe pelayanan, 3) tangibility, 4) reliability, 5) responsiveness, 6) emphaty, 7) assurance, 8) rekomendasi, 9) pelayanan tambahan atau masukkan dari klien.

Menurut focus group discussion yang telah dilakukan oleh penulis, pengetahuan mengenai firma hukum MAP diketahui dengan berbagai cara. 2 dari klien mengatakan bahwa mereka mengetahui firma hukum MAP dari teman atau kolega sedangkan 2 lainnya mengatakan bahwa mereka mengetahui mengenai firma hukum MAP dari televisi. Sedangkan tipe pelayanan yang didapatkan dari firma hukum MAP kepada keempat klien tersebut adalah mengenai perkara hukum tata negara.

Tangibility atau elemen dari service quality yang didapatkan yang pertama adalah berisi mengenai komunikasi yang terjalin antara klien dengan advokat. Yang mana komunikasi terjalin dengan baik. Yang kedua adalah mengenai image atau tampilan firma hukum MAP. Menurut keempat klien image yang ditampilkan sangatlah baik. Sedangkan yang ketiga adalah mengenai pengelolaan dokumen legal yang ditangani oleh firma hukum MAP. Pengelolaannya juga sangat baik karena beberapa dari klien yang penulis wawancarai pernah meminta dokumendokumen lama yang sebelumnya dibuat dari firma hukum MAP masih terjaga dan tertata rapi. Sehingga menurut mereka, firma hukum MAP memiliki pengelolaan dokumen yang baik yang dapat sewaktu-waktu diminta oleh klien untuk memberikannya untuk prosedur referensi dalam penanganan kasus para klien tersebut.

Reliability yang juga merupakan elemen dari service quality juga berperan dalam service quality assessment dari firma hukum MAP yang berfokus pada yang pertama adalah ketergantungan klien pada pelayanan oleh firma hukum MAP. Keempat klien firma hukum MAP mengatakan bahwa mereka dapat bergantung pada pelayanan dari firma hukum tersebut dari segi legal opinion dari advokat yang dapat diandalkan oleh klien. Yang kedua mengenai ketepatan pelayanan dari pelayanan oleh firma hukum MAP. Keempat klien mengatakan bahwa pelayanan yang dilakukan oleh MAP sudah tepat karena apabila ada perubahan jadwal sidang, klien langsung diberitahu. Yang ketiga mengenai kekinian dan keakuratan informasi yang diberikan oleh firma hukum MAP. Keempat klien mengatakan bahwa informasi yang diberikan oleh MAP sudah akurat dan terkini karena klien diberitahu apabila ada dokumen yang harus dipersiapkan ketika sidang dan apabila ada hal yang dikira belum memenuhi, klien langsung diberitahu dan diberi jeda sehingga dapat mempersiapkan diri. Dan yang keempat mengenai kebebasan membuat kesepakatan dengan firma hukum. Keempat klien tersebut mengatakan bahwa mereka diberi kebebasan dalam hal membuat kesepakatan dalam mendapatkan pelayanan hukum dari firma hukum MAP.

Responsiveness juga merupakan salah satu elemen dari service quality. Responsivenss dalam focus group interview ini memfokuskan pada yang pertama kecepattanggapan firma hukum MAP dalam memberikan pelayanan. Menurut pendapat keempat klien tersebut, firma hukum MAP sudah cepat tanggap dalam 
melayani klien. Yang kedua adalah keproaktifan firma hukum MAP dalan mengatasi masalah. Keempat klien tersebut mengatakan bahwa mereka puas dengan keproaktifan advokat di firma hukum MAP karena advokat MAP dapat memberikan masukkan yang sesuai dengan kemajuan proses hukum yang ditempuh dalam melayani klien dalam persidangan.

Empathy dalam focus group discussion ini memfokuskan pada pendekatan yang dapat dilakukan oleh firma hukum MAP dalam melayani klien. Keempat klien berpendapat bahwa sebuah firma hukum harus memiliki pendekatan yang berbeda karena setiap klien memiliki isu hukum yang berbeda dan firma hukum MAP sudah memiliki itu semua.

Assurance dalam focus group discussion ini yang pertama memfokuskan pada kualitas yang dimiliki oleh firma hukum MAP. Menurut keempat klien yang penulis wawancarai, firma hukum MAP memiliki kualitas dalam segi transparansi dan memenuhi ekspektasi klien mengenai bagaimana proses hukum tersebut berjalan. Yang kedua memfokuskan pada kualifikasi legal yang dimiliki oleh advokat MAP. Menurut keempat klien tersebut, para advokat MAP sudah memiliki kualifikasi legal dalam beracara di pengadilan karena mengetahui mengenai prosedur hukum seperti pelatihan saksi dan membuat keputusan legal yang logis dan perlu. Yang ketiga memfokuskan pada reputasi MAP. Menurut keempat klien tersebut, reputasi MAP dapat dipercaya karena MAP master dibidang hukum. Yang keempat memfokuskan pada masukan yang diberikan oleh MAP kepada klien. Menurut keempat klien, firma hukum MAP sudah berhasil dalam memberikan masukan pada klien.

Berdasarkan rekomendasi dari klien, para klien akan merekomendasikan firma hukum MAP pada keluarga dan kolega mereka karena sudah puas dengan pelayanan yang diberikan oleh firma hukum MAP. Berdasarkan pendapat klien, pelayanan tambahan dari firma hukum MAP yang dapat ditawarkan adalah firma hukum MAP dapat mengembangkan sayap dibidang hukum perusahaan atau korporasi.

Sebagai kesimpulan, berdasarkan pendapat keempat klien tersebut tidak ada service gap yang signifikan dalam kualitas pelayanan dari firma hukum MAP. Pelayanan sudah memuaskan dan sangat direkomendasikan oleh klien kepada keluarga dan koleganya.

\section{In-depth Interview}

Penulis juga telah melakukan in-depth interview dengan salah seorang associate di firma hukum MAP yang bernama Ibu Vivi Ayunita. Didalam interview tersebut terdapat pembagian fokus mengenai waste elimination sebagai salah satu strategi operasional dari firma hukum MAP dalam mempertahankan kualitasnya sebagai firma hukum yang kompeten dalam bidangnya. Waste elimination tersebut memiliki konstituen yang terfokus pada defects, over production, non-utilized talent, transportation, dan extraprocessing.

Berdasarkan interview yang telah dilakukan dengan Ibu Vivi dapat disimpulkan bahwa legal error (waste) adalah sesuatu yang dapat terjadi kapanpun. Tetapi dalam praktiknya, menurut Ibu Vivi, firma hukum MAP tidak 
pernah membuat legal error dalam pelayanannya dibidang hukum. Akan tetapi apabila terjadi legal error, hal tersebut harus dikomunikasikan dengan klien dan dicari solusi yang terbaik seperti menyediakan alternatif-alternatif atas permasalahan yang ada dan membiarkan klien memilih alternatif yang terbaik untuk menyelesaikan masalah. Riset lebih lanjut mengenai perkara yang ditangani juga harus dilakukan.

Melalui Ibu Vivi, penulis dapat menyimpulkan bahwa over production sangat mengganggu kelancaran jalannya perkara yang ditangani oleh firma hukum MAP. Over production dapat terjadi ketika seorang advokat membuat banyak dokumen yang tidak sepenuhnya memiliki isi yang relevan terhadap perkara itu sendiri. Menurut Ibu Vivi, firma hukum MAP tidak pernah mengalami over production. Firma hukum MAP mengatasi over production dengan cara tidak menggunakan pengulangan kata dan mempertahankan substansi secara jelas dan relevan dengan kasus dan tidak adanya redundancy dalam penyusunan kata dalam dokumen perkara.

Menurut Ibu Vivi, non-utilized talent dalam dunia kerja disebabkan oleh politik di kantor. Sebagai contoh, seorang pekerja yang kurang berkomunikasi dengan atasan dianggap tidak kompeten dan tidak diberikan banyak tugas dan tidak diberikan kesempatan untuk diberdayakan. Tetapi dalam firma hukum MAP, tidak pernah terjadi hal seperti politik kantor. Untuk mengatasi hal tersebut, atasan dapat mengirim advokat untuk diberikan pelatihan-pelatihan hukum serta diskusi internal mengenai performa advokat dengan advokat itu sendiri dalam periode yang telah ditentukan oleh atasan.

Berdasarkan interview yang telah dilakukan dengan Ibu Vivi, dalam hal transportation, dapat disimpulkan bahwa pemindahan informasi antara advokat dengan klien dilakukan dengan cara praktis melalui email atau tidak lagi dalam bentuk fisik. Firma hukum MAP juga berpendapat bahwa pemindahan informasi secara digital tersebut lebih efektif dan efisien sehingga dapat meminimalisir biaya transportasi dalam pemindahan informasi dalam kasus yang ditangani.

Berdasarkan interview yang telah dilakukan, dalam hal extraprocessing terutama mengenai workflow, dapat disimpulkan bahwa langkah-langkah dalam cara kerja para advokat di MAP sudah cukup baik dikarenakan tidak adanya kompleksitas dari chain of command dalam menangani perkara yang ada. Hal ini juga disebabkan karena hanya ada satu managing partner yang menjadi ujung tombak dalam pengambilan keputusan sehingga tidak ada hambatan dalam workflow. Sebaliknya apabila di MAP memiliki long chain of command akan banyak masalah yang terjadi seperti lambatnya pengambilan keputusan, penyelesaian perkara dan komunikasi antara managing partner dan associates. Dalam hal ini dapat disimpulkan bahwa firma hukum MAP sudah mengaplikasikan waste elimination dalam kehidupan perkantorannya baik dari segi defects, over production, non-utilized talent, transportation maupun extraprocessing. 


\section{E. SIMPULAN}

Service quality yang dimiliki oleh firma hukum MAP sudah cukup baik dari segi pengelolaannya karena tidak adanya service quality gap dalam implementasi dari service quality. Service quality yang dilakukan oleh firma hukum MAP sudah juga sudah sesuai dengan prosedur hukum yang berlaku. Dengan demikian firma Hukum MAP juga dinilai berhasil dalam menjaga kompetensinya dalam melayani klien dalam menghadapi perkara yang dihadapi. Sedangkan dari segi strategi operasionalnya, firma hukum MAP juga memiliki strategi operasional dalam hal waste elimination. Firma hukum MAP dinilai telah sukses dalam mempertahankan kualitasnya sebagai penyedia layanan hukum dikarenakan setiap langkah dalam penyelesaian perkara telah direncanakan terlebih dahulu dan setiap masalah dalam perkara dapat ditangani secara optimal oleh para advokat. Dengan mengimplementasikan waste elimination dapat memperlancar jalannya perkara yang ditangani oleh para advokat MAP dan dapat menciptakan efisiensi dan efektivitas dari proses penanganan perkara baik melalui litigasi maupun nonlitigasi.

Sebagai rekomendasi untuk pelaksanaan pelayanan oleh firma hukum MAP di masa depan adalah dengan memfokuskan pada contionous improvement dan continuous learning serta CRM. Continous improvement itu sendiri berhubungan dengan kualitas proses bisnis dari MAP itu sendiri. Waste elimination yang telah dilakukan oleh MAP sudah cukup baik tetapi seiring beberapa periode berjalan, perbaikan mutu dari proses bisnis itu harus tetap dilakukan. Contionous improvement itu sendiri dapat dilakukan apabila ada continuous learning. Continous learning memudahkan MAP untuk memperjelas area of improvement yang harus dilakukan untuk menciptakan kualitas servis yang berkualitas tinggi dan menjamin kepuasan klien. Continous improvement dan continuous learning itu sendiri dapat dilakukan dengan melakukan benchmarking dengan best practice law firm. Untuk penggunaan CRM sendiri adalah untuk menjaga hubungan baik antara advokat dan klien. Dengan paperless office juga dapat membantu advokat yang menghadapi banyak paperload dan dengan mudahnya menangani dokumentasi serta transfernya atas perkara klien dan semua itu dilakukan dengan cloud computing. Software untuk proses bisnis ini juga mampu meningkatkan efisiensi dan meningkatkan kualitas pelayanan perusahaan. 


\section{DAFTAR PUSTAKA}

Lisa Glanakos. (2014, April 20). An Introduction to Lean Six Sigma As Applied to the Law Firms. Practibce Innovations, pp. 12-18. Retrieved from https://info.legalsolutions.thomsonreuters.com/signup/newsletters/pr actice-innovations/2014-oct/article4.aspx

Mulia, T. G. M. (2011). IMPLEMENTASI SISTEM MANAJEMEN MUTU ISO 9001: 2008 PADA PERUSAHAAN JASA KONSTRUKSI. UNIVERSITAS ATMA JAYA YOGYAKARTA. Retrieved from http://ejournal.uajy.ac.id/2040/3/2TS12807.pdf

PARASURAMAN, A. and V. A. Z. (1988). 7d007e04d78261295e5524f15bef6837.pdf. Journal of Retailing, 64(SERVQUAL). $\quad$ Retrieved from https://search.proquest.com/openview/7d007e04d78261295e5524f15 bef6837/1?pq-origsite=gscholar\&cbl=41988

Shahin, A. (2010). Developing the Models of Service Quality Gaps : A Critical Discussion. Business Management and Strategy, 1(1), 1-11. Retrieved from

https://pdfs.semanticscholar.org/4c7a/0af8d73395a9621dcc6fba0981 bcfaaf5f95.pdf 